\title{
How gezhemgen, the oak manna, has been forgotten in Dersim (Tunceli) in the Upper Euphrates basin: extractive capitalism and local knowledge
}

\author{
Gülkızılca Yürür1
}

Altınbaş University, Turkey

\begin{abstract}
This study contributes to the literature on the effects of extractive capitalism on sedentary subsistence herding and the loss of traditional knowledge, in this case about a wild edible, the oak manna gezhemgen. I present local narratives explaining the relationships between oak forests, climatic conditions and the agricultural cycle in Eastern Anatolia, Turkey. Gezhemgen is a sign of a good harvest and signifies the power of fertility (being also called "the power of Hizır", a deity). Pastoralist practices are affected by intrastate war and the appropriation of governance rights to grazing. There is a relationship between accessibility of pastures and the vertical transmission of knowledge on the flora of the highlands to young generations. Narratives were gathered during ethnographic fieldwork between 2011-2017 in the Pülümür, Ovacık, Nazımiye and Kalan districts of Dersim. The food gathering behaviors of local populations are also influenced by urbanization, military violence and expropriation of use rights on common grazing grounds. The article reveals multiple effects of the transitions from customary systems of sedentary pastoralism to commercialized modes of agricultural production.
\end{abstract}

Keywords: land relations, armed conflict, Eastern Anatolia, foraging, wild edibles

\section{Résumé}

Cette étude contribue à la littérature sur les effets du capitalisme extractif sur l'élevage sédentaire de subsistence, et la perte des connaissances traditionnelles sur la manne du chêne, gezhemgen. Je présente des récits locaux expliquant les relations entre les forêts de chênes, les conditions climatiques et le cycle agricole en Anatolie orientale, en Turquie. Gezhemgen est le signe d'une bonne récolte et signifie le pouvoir de la fertilité (également appelé "le pouvoir de Hızır", une divinité). Les pratiques pastorales sont gravement affectées par la guerre intra-étatique et l'appropriation des droits de gouvernance au pâturage. Il existe une relation entre l'accessibilité des pâturages et la transmission verticale des connaissances aux jeunes générations concernant les plantes des hautes terres. Des récits ont été recueillis lors de travaux ethnographiques sur le terrain entre 2011 et 2017 dans les districts de Dersim de Dersimülümür, Ovacık, Nazımiye et Kalan. Les comportements de collecte de nourriture des populations locales sont également influencés par l'urbanisation, la violence militaire et l'expropriation des droits d'usage sur les pâturages communs. L'article explore la transition du pastoralisme sédentaire coutumier vers des modes de production agricole commercialisés.

Mots-clés: relations foncières, conflit armé, Anatolie orientale, recherche de nourriture, comestibles sauvages

\footnotetext{
${ }^{1}$ Dr. Gülkızılca Yürür, Assistant Professor, Department of History of Medicine and Medical Ethics, Altınbaş University Medical Faculty, Istanbul, Turkey. Email: kizilca2002 "at" yahoo.com, gulkizilca.yurur "at" altinbas.edu.tr. Acknowledgements: the study is part of an extensive oral history project, "The healing tradition of Dersim Alevis" in Eastern Anatolia, currently extending into Sivas and Erzincan districts, and funded by the Scientific Research Fund (BAP) of Istanbul Altinbas University, no. PB2016 - GÜZ TIP 7. The author would like to thank Prof. Simon Batterbury for his accurate, labour-intensive contributions and editing work, and two referees of the Journal of Political Ecology for insightful comments and guidance for the revisions.
} 


\section{Özet}

Bu çalışma, özütlemeci kapitalizmin (ekstraktif kapitalizm) geleneksel bilgi ve yerleşik geçimlik hayvancılık üzerindeki etkilerini, bir yabani yenilebilir gıda olan meşe balı gezhemgen örneğinden yola çıkarak tartışacaktır. Makalede, Doğu Anadolu bölgesinde meşe ormanları, iklim koşulları ve tarımsal döngüler arasındaki ilişkiye odaklanan yerel anlatılar sunulmaktadır. Gezhemgen, verimli bir hasatın ve bereketin bir göstergesi Kabul edilmekte ve bir bereket evliyası olan Hızır ile ilişkilendirilerek, "Hızır'ın kudreti” olarak da adlandırılmaktadır. Hayvancılık pratikleri iç savaş koşullarından ve devletin yasal düzenlemeleriyle otlatma alanlarının kullanım haklarının yerel yerleşimlerin elinden alınmasından etkilenmiştir. Ancak, yaylalara erişimle, yaylalardaki bitki zenginliğine dair geleneksel bilginin genç kuşaklara dikey aktarımı (yaşlı kuşakların gençlere öğretmesi) arasında yakın bir ilişki bulunmaktadır. Sunulan anlatılar, 2011-2017 yılları arasında, Dersim'in Pülümür, Ovacık, Nazımiye ve Kalan ilçelerinin köylerinde yapılan alan çalışmasında derlenmiştir. Yerel halkların doğadan besin toplama davranışları, kentleşme, askeri şiddet ve ortak mükiyet olan meraların kullanım haklarının insanların tasarrufundan alınmasından etkilenmektedir. Bu makalede, tarımsal üretimin sınai ve ticari örgütlenme biçimlerine geçişin, geleneksel yerleşik hayvancılık sistemlerini nasıl etkilediği, çeşitli sonuçlar tartışılarak konu edilecektir.

Anahtar kelimeler: Tarımsal üretim ilişkileri, silahlı çatışma, Doğu Anadolu, gıda toplayıcılığı, yabani yenilebilir bitkiler.

\section{Introduction}

Intrastate wars are responsible for the devastation of habitats and increased social injustices (Garbarino \& Kostelny 1996; Smith 1997). Armed conflict, and uneven power relations in the control of natural resources can lead to various forms of environmental degradation and the dissolution of traditional routines and behaviours that have successfully sustained local livelihoods (LeBillon \& Duffy 2018, 241). In this article, I focus on the effects of widespread conflict on the gathering of wild edible manna or honeydew (gezhemgen) from oak trees (Quercus spp.) in Dersim in Eastern Anatolia. ${ }^{2}$

Dersim has seen intermittent interstate war, described in written and oral accounts, with material consequences for foodways and rural livelihoods. Villages have been evacuated, accompanied by the dispossession and state appropriation of agricultural land and pastures. Interaction with wilderness, and knowledge of the medicinal properties of plants, has been compromised. The accounts of elderly residents about the gathering of oak manna provides a glimpse into the fabric of social memory by addressing places, cycles, objects and the "banal temporalities" of food production (Ange and Berliner 2014, 2) within an economy that was largely self-sufficient up until the early 1950s. This is when integration into the Turkish economy began, driven by the neoliberal values of a 1948 Marshall Plan signed with the USA (N. Koç, B. Koç 2017, 83).

As Mattalia et. al. note, traditional pastoralist practices and associated knowledge plays a crucial role in shaping relationships among people, animals and the surrounding ecosystem (Mattalia et al. 2020, 2). Teklehaymanot and Giday report from the semi-pastoralist Kara and Kwego people in Ethiopia that they still rely on wild edible foods gathered in times of scarcity, and this may account for an extraordinary species richness in their accounts (Teklehaymanot and Giday 2010, 1-8). Sharafatmandrad and Mashizi compare the herbal knowledge and food gathering behaviour of eight nomadic tribes and ten villages in southeastern Iran, all of them pastoralists. They find that the relative loss of medicinal plant species was higher under a sedentary pastoralist regime, as the selling of medicinal plants became an additional income source. Medicinal plants with higher social value were particularly vulnerable to overexploitation, and there was strong commercialization of a small number of well-known species with multiple medicinal uses (Sharafatmandrad and Mashizi 2020, 12). As Barreau et al. observe, a sustainable regime of plant use is a learning event, whereby transmission of knowledge is horizontal (within the same generation) and vertical

2 Honeydew is a sugary excretion from plant sap, sucked in and excreted by insects such as aphids. The oak trees continue to bleed a white sugar crust called manna. It is this which was collected, seasonally, in the region and processed and consumed. 
(from elder generations). Both connect humans to plants (Barreau et al. 2016, 413). Yet, horizontal and vertical knowledge pathways are tightly sensitive to changes in generational and inter-generational perceptions of the land, and therefore historical and contemporary socio-ecological events structure ethnobotanical knowledge transmission (Barreau et al. 2016, 413).

The perception and processing of gezhemgen needs to be framed by a discussion of extractive capitalism over time, including the large-scale transformation of pastoralism, the most dominant form of production in Eastern Anatolia. It is also influenced by hydro-electric power plant and dam projects (see for example Ağar, Böhm, 2018; Eren 2017; Goner, Rebello 2017; Törne 2015) and numerous, mostly un-realized mining projects. I focus on lived experience and the broader historical context of war and transformation rather than these infrastructures, in order to connect the dots between stories of the cyclical temporality of agricultural production within a subsistence economy, and the linear flow of political and economic domination within a system of extractive capitalism, intensifying after large-scale village evacuations of 1994.

\section{The study region}

The East Anatolian province of Dersim suffered an extremely violent massacre by military forces, termed by several Dersim researchers as a genocide, in the early days of the Turkish Republic in 1938. The long-term military operation resulted in large-scale evacuation of villages, and the deportation of the local Alevi Zaza populations to West and Central Anatolian cities, from where most families only returned to their home villages over the next ten to fifty years (Deniz 2020). In the early 1990s, armed conflict between the Kurdish guerrilla organisation PKK and the Turkish military made rural settlements and pastures inaccessible. Since 1994, almost all mountain villages have been gradually evacuated and most of them remain empty. Out of the 399 villages in the province, 110 were evacuated and 64 were burnt to the ground by 1995 (Dinç 2021, 111). Until the mid-1990s, the province experienced major economic disintegration due to these forced village evacuations (Aktağ 2019, iii). Some districts have remained closed military zones for thirty years, especially in Ovacik (O'Connor 2014, 208).

Ecological degradation resulted. Numerous dam projects were initiated by the Turkish state on small and large rivers, described by Goner and Rebello as a "continuation of state violence against outsider populations" (Goner and Rebello 2016, 33). They refer to the outsider religious and ethnic identities of Dersim, which diverge from the Sunnite, Turkish majority in Turkey. Forest fires progress through Dersim during summer months. Joost Jongerden cross-references satellite data with geo-referenced eyewitness accounts to show that that between the early 1990s and 2006, the Turkish army burned forests, fields and villages in their conflict with the insurgent Kurdish guerrilla organisation PKK (Jongerden 2017, 1). Shahpurwala, using remote sensing and GIS has also shown how the ignition of forest fires by the Turkish army in conflict areas increased and continued to 2018 (Shahpurwala 2019, iii). Data for the last three years is unfortunately not available, but the pattern is that the domesticated worlds of fields, pastures, orchards and gardens not only suffered from degradation and destruction of land cover, but also from the heavy expansion of military bases, surveillance complexes and checkpoints (Dinç 2021, 109-110).

Migration due to armed conflict reduced the number of active rural settlements in Dersim, as the inhabitants of the evacuated villages migrated to the city centers of Dersim, Kalan, or to urban centers elsewhere in Turkey and abroad. Jongerden et. al. suggest that between 1990-2000, the total number of people living in the Tunceli countryside fell by a little over half (Jongerden et al. 2008, 5). Today, it is the province with the lowest population density in Turkey (internet source 1).

Our informants revealed decreasing opportunities for self-sufficiency and agrarian production in villages, the forced migration of rural populations to urban environments over 80 years, and discrimination against Alevi populations in the labour market in a Sunni-dominated Turkey. One outcome has been a high participation in higher education among the young, urban Dersim inhabitants. Dersim is one of the provinces with the highest rate of human capital investment and human capital output scores, ranking among the top ten cities in terms of higher education participation (Jeremic et al. 2016, 234-235). Although in East Anatolia region, problems "in the transformation of human capital investments into human capital stock" are reported, Dersim (mentioned as Tunceli in their report) stands out, ranking sixth in the country in human capital output scores, with "a high ratio of people with a high school, undergraduate or graduate diploma to the total 
population" (Jeremic et al. 2016, 238-239). This translates into a high level of mobility on the job market, but this means it is increasingly difficult to sustain productive rural populations in villages. The low population density in the rural areas is one of the reasons the Turkish government uses for making "structural changes and reforms in Turkish agriculture" (Republic of Turkey Ministry of Food Agriculture and Livestock 2003, 44), which has had serious consequences for communal lands in Dersim.

In 2007 the government changed the Pasture Law (4342 sayılı Mera Kanunu), transferring the right to rent out unused common pastures from the village administrations to the "pasture committee" of the city governorships. Since 2015, between May and September every year, large pastures in Ovacık and Pülümür have become populated with thousands of sheep and goats belonging to Şavak tribespeople, who are known for labour-intensive, large scale production of the region-specific Tulum cheese for the global market (Gültekin 2019). With the heavy grazing of pasture lands by this large pastoralist tribal group from the districts of Çemişgezek and Pertek on the outskirts of Dersim, the vertical movements of local small cattle holders diminish and opportunities for beekeeping decrease.

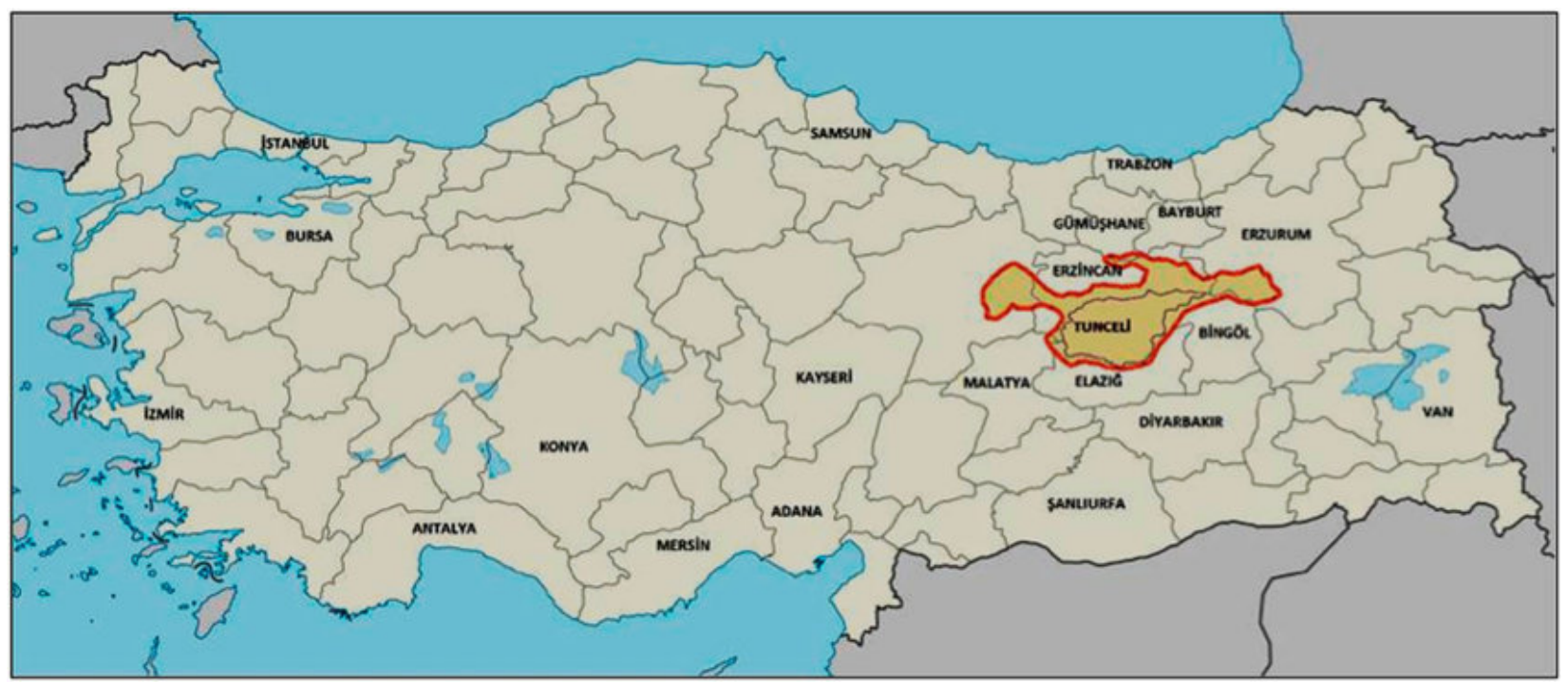

Figure 1. Districts of Dersim. Source: Dinç, 2016.

\section{Methods}

The oral narratives presented in this article were gathered during fieldwork in Dersim between 20112017, with intermittent visits some of which lasted a week, and others up to three months. The fieldwork was conducted as a part of a research project entitled "The healing tradition of the Dersim Alevis", and healers, healer families and lay people with a healing story were interviewed in 83 villages of the Mazgirt, Hozat, Nazımiye, Pülümür, and Ovacık districts. These semi-structured interviews discovered places of healing, agents of healing, healing stories, discourses of disease etiology, healing herbs and wild foods. Local Dersim researchers participated, easing participant observation of healing rituals, medicinal plant gathering, and informal discussions on highland pastures. The narratives about gezhemgen came up in response to our questions about wild edible foods, although it also seemed to have mystical healing properties. Our respondents said it seemed to rain from the sky, in times of dire need. We were able to establish a relationship between Hizır and healer families: Hizır was reported to have visited and bestowed healing capacities upon the healer family lines we interviewed.

After we started asking questions about gezhemgen, we soon realized that the name was alien to locals under the age of fifty. The age group between 50 to 70 would remember gezhemgen, although most of them 
could only recall it being collected and processed by their mothers. Those older than seventy were the ones who actively collected gezhemgen in their young years, while villages were still populated. At that time, almost no food aside from tea and sugar came from the neighbouring urban centers or districts. We were able to gather 20 gezhemgen narratives, but those presented here are especially informative in situating gezhemgen in the broader cycle of agricultural production, and the lived experience of gathering, processing and eating it, including its taste, color and texture.

The material is approached from the position of an "embedded interpretant", building "an ontology that turns on signs, objects, and interpretants instead of causes and effects and thus the categories" (Kockelman $2015,154)$. Changing ways of food procurement and choices are a condition for, and consequence of semiotic processes embedded in specific relationships of conflict, competition and cooperation between social groups. To think this way broadens the perspective on food procurement and choices, as they are affected by social conflicts over forest resources, protected areas, agricultural regimes, or productive regions, as well as by historical processes of transformation of nature and of the relationships between social groups (LeBillon 2001, 563). The methodological aim of this study also aligns with the suggestion that research in political ecology "explores the power relations between society and nature as embedded in social interests, institutions, knowledge and imaginaries that weave the life-worlds of the people" (Tetreault 2017, 3; Leff 2015).

Darcy Tetreault argues that in the field of political ecology, there are two broad methodological approaches: materialist, associated with Marxist political economy, and the post-structuralist, using discourse analysis and with a focus on the social construction of environmental issues, which can in turn influence material events. A third form of political ecology transcends this divide (Tetreault 2017, 4). He notes that some contributions derive questions from ecological Marxism, articulating an analysis of both the subjective/discursive and objective/material conditions of agency formation, as involved in understanding social environmental movements and conflicts (Tetreault 2017, 4). This study gathered data and made sense of it within this "third form", showing how the web of events surrounding the emergence of gezhemgen are "constructed by specific meaning-giving and discursive processes" and are affected by socio-environmental conflicts (Escobar 1992, 1-2).

\section{Gezhemgen in Dersim in past times}

Gezhemgen has been used in Dersim as a general remedy for boosting the constitution and for providing good nutrition for children and the elderly, especially in winter. It was known for "healing the sick and giving power to the weak." Heated up and mixed in butter, it was served as a special treat to guests. In mountainous Dersim, where access to refined sugar was very limited, this sweet was valued highly, supplementing precious sweet foods like sugar and honey.

The 76-year-old Sabiha Özer from the village of Grzge narrated the preparation of Gezhemgen as follows:

My mother would pick up the dare (sickle) and go to the forest to cut the leaves, in fall. They call it the mystery of Hizır (Hizır'ın sirrı), or also the power of Hizır (Hizır'n kudreti). We would take sheets with us, we would spread the leaves on the sheets at home, they would lay around spread for a week, to dry. Then my mother would nicely beat them, slowly beat the leaves with the rolling pin so that honey would come down from the leaves. This is then passed through the prizine (a coarse sieve), gezhemgen collects underneath. We sieve it one more time with a finer sieve, and the leaves, which are heavier remain on top. The dust which falls down is collected and made into a dough. There are leather bags called manuk. They press this dust into those leather bags, bags press it into the leather with a kavuk (knob). You press it really hard, just like you press çökelek (skim-milk cheese), and it will be hard like a piece of stone in the manuk. This is how you prepare for winter. In wintertime, they cut this hard thing into small pieces. When you give this to children, they will feel full immediately; it satisfies hunger very fast. It makes them resistant to heavy colds. When a good guest comes, they put it into butter, cook it well with butter, and this is a real feast, a food really worthy of a landlord ( $a \breve{g} a$ yemeği). 
Her son İbrahim, a 52-year-old computer technician living in Dersim city, knew less about the cooking and preparation of honeydew, but was more interested in why people historically associate gezhemgen with Hizlr, and what it says about life conditions in the old times:

Gezhemgen is some sort of honey that emerges on oak leaves in the fall. The oak tree creates this honey out of its own essence. In the fall, it emerges out of nowhere. It does not emerge everywhere. You never know where and when exactly it will appear. In 1938 our people could survive thanks to this. This is why they call it "the power of Hizır", as it comes to the urgent help of people who are starving, who are in dire need. In times of famine and scarcity, there would be lots of it, they would press big amounts of gezhemgen into big canisters. As it emerges out of nowhere in times of need, we believe that Hizır makes it for the people.

Bako Menteş (at the time of the interview in his late '80s), a local healer especially known for his skin ointments, also observed gezhemgen as a power that becomes manifest. In his recollections, he made use of a connection with the cyclic work rhythm in the village and the time of gezhemgen emerging:

I don't think that gezhemgen is raining down from the sky. It is something that the oak tree is pulling out from the soil, getting it out by its own power, from its bark maybe. In some years the trees would be so full of power that the gezhemgen would rain down from the leaves onto the sheep, the sheep's wool would be all sticky. We cut grass in June, sometimes there is plenty of grass, we cut and store them in the barns, and in July, gezhemgen would start to emerge. But it would not come out every year, only in some years. Then the elderly would say: 'gezhemgen rained well this year, Hızır is fertile this year, Hızır's fertility is high, Hızır is powerful this year.' They would say, 'When Hizır is high in power, we have a good harvest.' It would really be a highly fertile year each time, with much rain in spring and a good harvest. For example, there was none last year, but this year it came out. This year, we also have plenty of water.

The observation that there is a relationship between abundance and fertility and the occurrence of honeydew on oak leaves may be the reason why in Dersim, gezhemgen was also named "the power of Hizır", the sacred harbringer of spring. Hizır is known in the Anatolian peninsula as a sacred power who helps good people in need. In the traditional agricultural calendar, the months between May and November are the "Hizir months." Abundant gezhemgen, a strengthening power which flows between the oak, humans and Hizır the immanent (Hızır her yerde hazır ve nazır), signalled abundant fertility (bereket) and the powerful presence of Hizır in Dersim that year. Although the small number of interviews conducted in the neighbouring Sunnite provinces of Elazığ and Erzincan and Sivas were not representative of the entire population, we found gezhemgen is not eaten there, and little known. The veneration of Hizır, very visible in Dersim, is rare to non-existant in the neighbouring rural and urban areas. Among the dominantly Sunnite populations, the idea that Hizır has the status of a fertility deity would be considered blasphemous.

The oak forests covering large areas in Dersim stretch over a range of Anatolian mountains, reaching all the way east towards the Zagros mountain range in Iran. Yazdanparast et al. report from the west of Iran that in the local markets, the oak manna Gaz-Alafi is also called "Gazu" or "Kurdish Gaz", and is currently used along with the less popular, but still traded, willow manna, Bid-Khesht (Yazdanparast et al. 2014, 1026). Considering the popularity of gezhemgen in the "Kurdish" parts of Iran, it is possible that it is cultural knowledge of the Kurdish tribes, and with some probability, the formerly dominantly nomadic Kurdish populations crossing the Taurus and Zagros mountain ranges (Bois 1966, 12-13). The name "Kurdish Gaz" or ghezo, implying oak manna, was reported by Rosenheimer in 1839, Hanbury in 1876 and Bodenheimer in 1947 (in Donkin 2013). Yazdanparast et al. also refer to oak manna as "Kurdish gaz" in their study on the nutritional values of several types of Iranian manna (Yazdanparast et al. 2014, 1026).

In Dersim, three different types of oak are distinguished in the local Zaza language: The Azgel oak with bright, small leaves, Moje şae with dark leaves and Velgo gewr with broad, dull, greyish leaves. 
Gezhemgen rains only on the Azgel and Moje şae leaves. Azgel seems to be Quercus infectoria and Quercus brantii is the Moje şae species. Oak-specific aphids Thelaxes suberi Del. and Tuberolachus annulatus Hart. feed from the sap of the leaves of these trees and secrete a hard, brilliant resinous sweet substance (Yazdanparats et al. 2014, 1026).

Gezhemgen appears on oak trees at different times in different districts. This may be related to altitude, with many villages on high, green mountain meadows. According to Kamer Sarıçiçek, a retired electronical engineer from the mountainous Nazımiye district, Gezhemgen rains down in August:

In August, honey rains down on the oak tree, yet it doesn't emerge every year. The leaves all become sweet, and the honey looks like dew on the leaves. We cut the leaves and dry them in the sun for a couple of days. The dried leaves are beaten up and sieved. After you filter the branchy parts, the rough bits, the remaining leaves with pure honey are kneaded into little balls. Its color is bluish, it is very hard. You have to heat it up for eating. It has a wonderful aroma. Just like they keep whiskey in oak barrels to give it a special taste, this gezhemgen has such a taste. It rains on the oak trees in the forest, and people call it "the power of Hizir." People would say, "gezhemgen rained down this year," they said it would rain down on oak trees, and they would give it to the sick ones. Those years would be especially good years with bountiful harvest, and there would be plenty of wild flowers.

In the summer of 2015, we were told that there was an impressive rain of gezhemgen on the oak leaves in the counties of Nazımiye and Pülümür, but not one villager bothered to prepare them. During seven years of fieldwork, we never secured a ball of gezhemgen. Aside from the structural conditions affecting local villages, women explained how hard it was to process just a small amount of gezhemgen. However, beekeepers would preferably move some hives into proximity or carve a natural hive for their bees in the body of an oak tree, producing abundant amounts of honey. It is also a common practice to place beehives under oak trees when gezhemgen flows. Several apiarists suggested that the honey produced by honeybees feeding on oak sweetdew is dark in color and has a spicy taste.

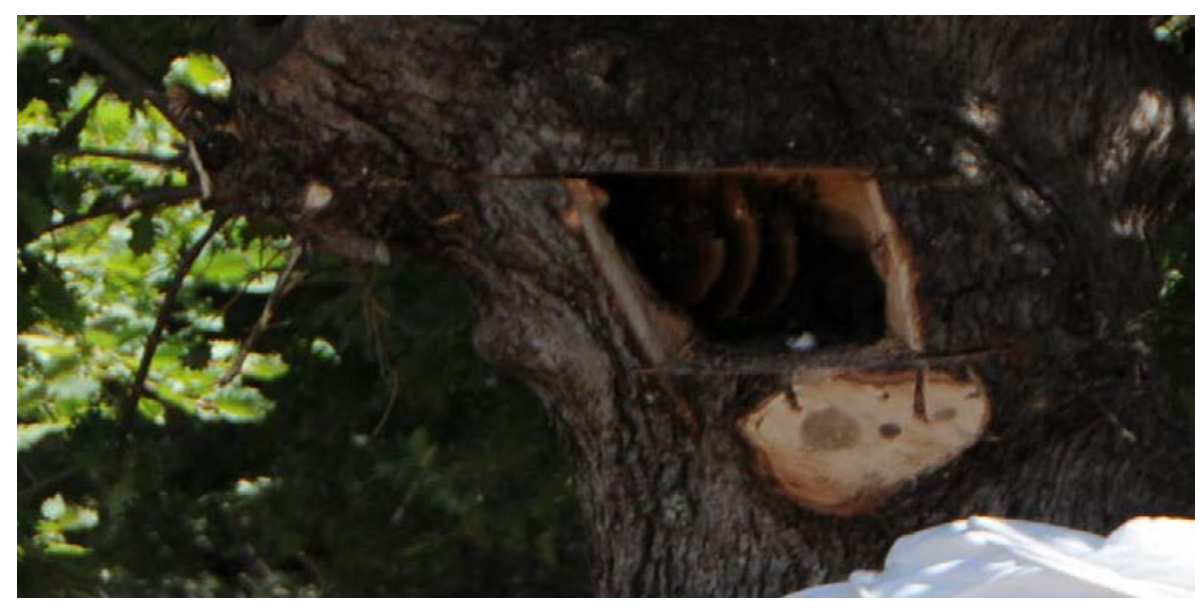

Figure 2: Beehive in an oak tree in Mazgirt county. Source:

https://www.milliyet.com.tr/galeri/agacin-icinden-cikariyorlar-500-liraya-satiyorlar-401578 


\section{The struggle over the pastures and the future of manna}

In Dersim today, where local herds are minimal in size, the village borders between fields, orchards and grazing land are continuously shifting. Wilderness partly takes over villages where humans are gone. While currently the Turkish military intensifies its operations against the PKK in northern Iraq, it carries out limited operations in Turkey's south east, providing some space for rural settlements to recover (International Crisis Group 2021). Intensifying every year since summer 2019, many families working in urban centers in Turkey and abroad have been re-building former family homes into new concrete houses, organizing water ways and re-opening roads in their home villages. While visiting the Xanolar village in Pülümür in 2018, I was told that even birds and small forest animals such as foxes and rabbits come back to the villages after humans gradually returned.

In Turkey, unemployment rates, especially for younger people, have been on the increase since 2012 (internet source 2). Along with fewer jobs in the cities, there is a slow and continuing tendency for those who have some land to return to in their home villages. But rearing cattle requires capital and labor, provided most cost effectively though family members who may not be available in numbers. Bee keeping requires neither, and is increasing in popularity. While in 2016, there were a total of 61,747 beehives in Dersim, in 2019 they numbered 165,911 (internet source 3). Most of the apiaries are small enterprises, with between fifteen to 100 hives. The honey producers are dominantly young Dersim villagers, with $70 \%$ of them between $21-40$ years old (Kutlu et al. 2017, 664). Almost all beehives are transported on trucks between spring pastures in Hatay, Mersin, Adana and Antalya districts along the Mediterranean coast, and summer pastures in Dersim.

Beekeepers run into conflict with industrial scale livestock owners, who rent pasture in Ovackk and Pülümür from May to October. The herds can reach 15,000 small cattle, sheep and goats, and they start eating off pasture flora by May. The owners of these big herds are from the Şavak tribes of Erzincan and Elazı who reach the grazing grounds in Pülümür and Ovacık from the neighbouring Pertek and Çemişgezek counties by early March. Pülümür is also the county with the highest number of beehives, and it has a beekeepers cooperative association with its commercially succesful honey label, "Hemgen." In April 2020 even before the pasture season started, a group of beekeepers, two village headmen and the county mayor of Pülümür county went to court to challenge the state practice of renting pastures, and the resulting exhaustion of the flora by extensive herding in Pülümür's Hel highlands (internet source 4). On May 13th 2020, the mayor of Pülümür county, two members of the mayorship assembly of Tunceli city, an agricultural development cooperative from Pülümür, 29 village headmen, 11 village associations located in urban centers in Turkey, and one village association located in Darmstadt, Germany organised a press conference and issued a press declaration against the overuse of pastures with the headline "Reaction to opening up the exhausted pastures to overgrazing", stressing the need to follow international regulations for the conservation of steppe ecosystems in Turkey, and specifically in Pülümür district (internet source 5).

As Dinç points out, "the networked and homeland-oriented political activist organizations" of Dersim people play a significant role in environmental activism in Dersim, publicizing any neoliberal attempts to capitalize on the region's land and natural resources (Dinç 2021, 49). The Dersim diaspora are also important to the local population in Dersim, as financial supporters. Aktağ refers to their role as small to mid-scale capital providers for local investments, exemplified in her work on the Munzur water bottling company (Munzur Su) (Aktağ 2019, 86-94). Dersim people living abroad, in Europe and urban centers in Turkey, also buy agricultural products from Dersim.

Several studies predict positive outcomes for small enterprises in Dersim organised around organic farming, sustainable rural production and rural cooperatives (Güner 2020; İzmen 2014). The current situation seems economically supportive of the local apiaries, but it remains to be seen how the conflict with the big cattle-holders over grazing lands will be resolved. As the head of the Tunceli Beekeepers Association remarked in an interview in 2018, gezhemgen is today known among beekeepers as 'bee food' and is highly sought after. If the current trend towards local honey production holds, it is possible that the oak manna will transform from being a halwa into a naturally available syrup for the bees. However, there needs to be a cultural preservation effort in order to transmit to the young beekeepers the perceptive capacities needed to observe the relationship between climatic conditions, the occurrence of gezhemgen and its function as signalling a good harvest. 


\section{Discussion}

Dersim is an examplar of the transformation of rural places afflicted by economic uncertainty and conflict. It receives little recognition due to its geopolitical complexity, and I have tried to explore its differentiated geographies of traditional cultural and livelihood practices which are faced with widespread dislocation and violence. Some of the new challenges to the region are visible in this quote by Martin Upchurch:

...After the financial crash of 2008, world trade declined and has been outpaced by sluggish growth in global production. The Covid-19 crisis and a fall in commodity prices in March 2020 has since driven the world economy into a slump that is likely to be more damaging than the Great Recession just over a decade ago. Within this changing scene, debates have arisen about the growth of extractivism - the mining and extraction of metals, minerals and oil from the earth-and the growth of agribusiness, which produces food as a traded commodity... (Upchurch 2020, 1).

Delgado Wise and Veltmeyer, focusing on the expansion of corporate capital in the agricultural sector, specify the dynamics of extractive capitalism as not so much the exploitation of human labor, but the looting and pillaging of natural resource wealth, especially advanced in countries on the periphery of the world system (Delgado Wise \& Veltmeyer 2018, 1-3). The taking of land, which in Dersim occurs through the renting out of village pastures to industrial-scale dairy producers by the hand of the state, is aiming at extracting economic value. The grazing conlict continues to affect small scale apiaries returning to the highlands for honey production, because local flora and fauna are destroyed by summer grazing. It begins too early for the wild plants to flower and to require pollination. Another indirect effect is eliminating the possibility for younger generations to occupy the pastures and "revitalize and maintain relationships of mutual obligation among humans and the other-than-human" (Burow, Brock \& Dove 2018, 57). They refer to "unsettling the land", in contrast to "caring for and collecting culturally important plants, the use of settler legal institutions to seek redress for dispossession and expand the landholdings of indigenous polities." This is being facilitated by Dersim communities in the county and abroad, especially in the Dersim diaspora in Germany (Burow, Brock \& Dove 2018, 58). The collection and archiving of traditional knowledge does take place alongside seeking legal recourse for destructive mining, construction and tourism projects. Gezhemgen is, therefore, embedded in efforts to decolonize land and territory.

This embeddedness is part of a relational ontology. The emerging oak honeydew spills over from being an indicator of Hizlr's immanent power into the material realm, enters the human body, becomes a signified power as soon as eaten and while being eaten, and it is transformed within the relationship. This is how the sign and the signified, objects and subjects, interact through transformative events: the sign flows over seamlessly into the signified (Alberti et al. 2011). As Ben Alberti suggests: "Once a relational ontology has been introduced, then by its very nature it challenges any attempt to erect barriers between something that can be called the real, material, or physical world and something else that can be called thought, discourse, or narrative. There is no position of externality" (Alberti et al. 2011, 905). From a position of total interrelatedness, Gezhemgen is situated within a semiotic act where the distinction between the material and the symbolic is lifted. Humans perceiving this immanent power - which is the manna - do not venerate, address or sanctify it; they just eat it.

\section{Conclusion}

Through flows between plants, animals and humans, and through food gathering and production, the domesticated and wild landscapes of the human world become intimately linked. Wild edible foods connect a directly material relationship with wilderness, to human awe in the face of wilderness. Forager narratives can be fruitful for understanding the effects of modes of food production on our perception of the world that is in, around, and beyond us. Armed conflicts and the expansion of industrial modes of agricultural production are imminent dangers to humans' knowledge about wilderness, and to forager behavior. Remembering wild edible 
foods has major value for local populations, especially for pastoral populations living in mountain environments, because they are part of communal survival. In one well-studied survey, the authors state:

There is substantial evidence that wild foods are an important part of the global food basket. At regional and national levels, food balances guide policies on trade, aid and the declaration of food crises. Notably absent from these is the contribution made by wild edible species. With the routine underestimation of wild foods comes the danger of neglecting the provisioning ecosystems and supportive local knowledge systems that sustain these food chains. (Bharucha \& Pretty 2010, 2913)

More research is needed on the ecology of pastoralism in Eastern Anatolia, in order to address problems of resource distribution, environmental change and the rapid loss of local knowledge systems. Sound data on food production and alternatives are needed for populations still recovering from armed conflict.

\section{References}

Ağar, C. C. \& Böhm, S. (2018). Towards a pluralist labor geography: Constrained grassroots agency and the socio-spatial fix in Dêrsim, Turkey. Environment and Planning A: Economy and Space, 50(6), 12281249. https://doi.org/10.1177/0308518X18776329

Aktağ, N. (2019). Dersim'de neoliberal dönemde yeni sermaye'nin oluşumu ve işçi sınıfının dönüşümü. (Capital formation and the transformation of the working class in Dersim in the era of neoliberalism). Masters thesis, Department of Political Studies and International Relationships. Istanbul: Istanbul University. (retrieved February 2020 from http://nek.istanbul.edu.tr:4444/ekos/TEZ/ET000690.pdf

Alberti, B., Holbraad, M., Marshall, Y. \& Witmore, C. (2011). Worlds otherwise: Archaeology, anthropology, and ontological difference. Current Anthropology 52(6), 896-912.

Ange, O. \& Berliner, D. (2014). Anthropology and nostalgia. New York: Berghahn Books.

Barreau, A., Ibarra, J. T., Wyndham, F.S., Rojas, A. \& Kozak, A. R. (2016). How can we teach our children if we cannot access the forest? Generational change in Mapuche knowledge of wild edible plants in Andean temperate ecosystems of Chile. Journal of Ethnobiology 36(2), 412-432. https://doi.org/10.2993/0278-0771-36.2.412

Bharucha, Z. and Pretty, J. N. (2010). The roles and values of wild foods in agricultural systems. Philosophical Transactions of The Royal Society B: Biological Sciences, 365(1554), 2913-2926. http://doi.org/10.1098/rstb.2010.0123

Bois, T. (1966). The Kurds. Beirut: Khayat.

Burow, P.B., Brock, S. \& Dove, M. (2018). Unsettling the Land. Environment and Society, 9, 57-74.

Delgado Wise, R. and Veltmeyer, H. (2018). Capitalist development and agrarian change on the Latin American periphery. Review of Political Economy, 9(2), 221-234. http://doi.org/10.13169/worlrevipoliecon.9.2.0211

Deniz, D. (2020). Re-assessing the genocide of Kurdish Alevis in Dersim, 1937-38. Genocide Studies and Prevention: an International Journal, 14(2), 20-43. https://doi.org/10.5038/1911-9933.14.2.1728

Dinç, P. (2016). Collective memory and competition over identity in a conflict zone: the case of Dersim. $\mathrm{PhD}$ dissertation. London: The London School of Economics and Political Science (LSE).

Dinç, P. (2021). Euro-Who? Competition over the definition of Dersim's collective identity in Turkey's diasporas. Turkish Studies, 22(1), 49-73.

Donkin, R. (2013). Manna: an historical geography. Berlin: Springer.

Escobar, A. (1992). Culture, practice and politics: anthropology and the study of social movements. Critique of Anthropology, 12(4): 395-432. 
Eren A., (2017). The political ecology of uncertainty: the production of truth by juridical practices in hydropower development. Journal of Political Ecology 24(1), 386-405. https://doi.org/10.2458/v24i1.20879

Jongerden, J., de Vos, H. \& van Etten, J. (2007). Forest burning as counterinsurgency in Turkish Kurdistan: An analysis from space. The International Journal of Kurdish Studies. 21(1): 1-16.

Garbarino, J., \& Kostelny, K. (1996). The effects of political violence on Palestinian children's behavior problems: A risk accumulation model. Child Development 67(1), 33-45.

Goner, O. \& Rebello, J. T. (2017). State violence, nature, and primitive accumulation: dispossession in Dersim. Dialectical Anthropology, 41: 33-54. https://doi.org/10.1007/s10624-016-9440-7

Gültekin, A.K. 2019. Şavak. In E. Gezik \& A.K. Gültekin (Eds.), Kurdish Alevis and the case of Dersim: historical and contemporary insights (pp. 99-116). New York: Lexington Books.

Güner, B. (2020). Tunceli ili'nde organik tarım; gelişimi ve sorunları (Organic agriculture in Tunceli County, developmental strategies and problems). Sosyal Bilimler Araştırma Dergisi, 9(1), 142-151.

International Crisis Group. (2021). Turkey's PKK conflict: a visual explainer. (retrieved Feb. 2020). https://www.crisisgroup.org/content/turkeys-pkk-conflict-visual-explainer

İzmen, Ü. (2014). Bölgesel kalkınmada yerel dinamikler: Tunceli modeli ve 2023 Senaryoları. FAM Yayınları. http://investintunceli.gov.tr/tr/files/2015-10-12_16-47-24-1444657644.pdf

Jeremic, V., Radojicic, Z. \& Dobrota, M. (2016). Emerging trends in the development and application of composite indicators. IGI Global. (retrieved Feb. 2021) https://www.igi-global.com/book/emergingtrends-development-application-composite/148514

Jongerden, J. (2017). Looking beyond the state: transitional justice and the Kurdish issue in Turkey. Ethnic and Racial Studies, 41(4), 721-738.

Kockelman, P. (2015). Four theories of things: Aristotle, Marx, Heidegger, and Peirce. Signs and Society, 3(1), 153-192.

Koç, N. \& Koç, B. (2017). Effects of Marshall Plan on Turkish Economy. Sociology Study, 7(2), 83-121. http://doi.org/10.17265/2159-5526/2017.02.003

Kutlu, M.A., Gül, A., Özdemir, F. \& Kılıç, Ö. (2017). A study on general structure and beekeeping activities of Tunceli." $4^{\text {th }}$ International Regional Development Conference Proceeding Book, Pp. 662-668. (retrieved Feb. 2020) https://tinyurl.com/evu4fptd

LeBillon, P. (2001). The political ecology of war: Natural resources and armed conflicts. Political Geography 20, 561-584.

LeBillon, P. \& Duffy, R. (2018). Conflict ecologies: Connecting political ecology and peace and conflict studies. Journal of Political Ecology, 25(1): 239-260. https://doi.org/10.2458/v25i1.22704

Leff, E. (2015). Political ecology_a Latin American perspective. Desenvolvimento e Meio Ambiente, 35, 2964. http://doi.org/10.5380/dma.v35i0.44381

Massicard E. (2017)[2013]. The Alevis in Turkey and Europe: Identity and managing territorial diversity. London: Routledge.

Mattalia, G., Sõukand, R., Corvo, P. Pieroni, A. (2020). Wild food Thistle gathering and pastoralism: an inextricable link in the biocultural landscape of Barbagia, Central Sardinia (Italy). Sustainability, 12: 5105. https://doi.org/10.3390/su12125105

O'Connor, F. P. (2014). Armed social movements and insurgency: The PKK and its communities of support. $\mathrm{PhD}$ dissertation. Political and Social Sciences Department. Florence: European University Institute.

Republic of Turkey Ministry of Food Agriculture and Livestock. (2003). Structural changes and reforms on Turkish agriculture, 2003-2013. Ankara, Republic of Turkey Ministry of Food Agriculture and Livestock Publications.

Shahpurwala, A. (2019). Conflict, narratives, and forest fires in eastern Turkey: A quantitative perspective with remote sensing and GIS. Lund University GEM thesis series 27. Lund: Department of Physical Geography and Ecosystem Science. 
Sharafatmandrad, M. \& Khosravi, M. (2020). An ethnopharmacological study of native medicinal plants and the impact of pastoralism on their loss in arid to semiarid ecosystems of southeastern Iran. Scientific Reports: Nature Research, 10: 15526. https://doi.org/10.1038/s41598-020-72536-z

Smith, A. (1997). The nature of warfare: power, bargaining, super weapons, elections and the democratic peace. Paper presented at the annual meeting of the Western International Studies Association, Davis, CA, October.

Teklehaymanot, T. \& Giday M. (2010). Ethnobotanical study of wild edible plants of Kara and Kwego semipastoralist people in Lower Omo River Valley, Debub Omo Zone, SNNPR, Ethiopia. Journal of Ethnobiology and Ethnomedicine, 6: 23. https://doi.org/10.1186/1746-4269-6-23

Tetreault, D. (2017). Three forms of political ecology. Ethics and the Environment, 22(2): 1-23.

Törne, A. (2015). "On the grounds where they will walk in a hundred years' time" - Struggling with the heritage of violent past in post-genocidal Tunceli. European Journal of Turkish Studies 20 https://journals.openedition.org/ejts/5099

Upchurch, M. (2020). Is there a new extractive capitalism? International Socialism: a Quarterly Review of Socialist Theory. 168 https://isj.org.uk/extractive-capitalism/

Yakar, Jak. (2006). Traits of nomadic people: ethnoarchaeological and archaeological research in Turkey. In Hauser, S.R. (Ed.), Die sichtbarkeit von nomaden und saisonaler besiedlung in der archäologie. multidisziplinäre annäherungen an ein methodisches problem. (pp. 45-63). Mitteilungen des SFB "Differenz und Integration"; Halle Orientwissenschaftliche Hefte 21.

Yazdanparats, S., Ziarati, P. \& Asgarpanah, J. (2014). Nutritive values of some Iranian Manna. Biosciences Biotechnology Research Asia.11(2): 1025-1029. DOI: 10.13005/bbra/1378

\section{Internet resources}

1) https://eacea.ec.europa.eu/national-policies/eurydice/content/population-demographic-situationlanguages-and-religions-103 en (12/2/2020)

2) https://data.oecd.org/turkey.htm (20/2.2020)

3) $\quad$ https://www.ordutb.org.tr/wpcontent/uploads/2020/01/Ar\%C4\%B1c\%C4\%B1l\%C4\%B1k-Raporu.pdf $(23 / 3 / 2020)$

4) https://www.pirha.net/pulumur-hel-yaylasinda-meralara-iliskin-yargi-sureci-baslatilacak-video214138.html/28/04/2020/ (23/3/2020)

5) http://www.ozgurdersim.com/haber/yorgun-meralarin-hayvanciliga-acilmasina-tepki-16263.htm (23/3/2020) 